\title{
HISTORIA OCH MINNE BLAND JUDARNA I 1950-TALETS SVERIGE \\ En recensionsartikel
}

\author{
Rita BRedefeld \\ Stockholm
}

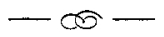

I december 193I, ett år innan nationalsocialisterna blev största parti i Tyskland och Hitler några månader därefter rikskansler, höll Skandinavisk-judiska ungdomsförbundet sin tolfte kongress i Stockholm. Kongressen framhöll nödvändigheten av ett sammanhållande organ mellan förbundets föreningar. Så tillkom tidskriften Judisk krönika. Det första numret kom ut 1932, samma år som Sverige fick en socialdemokratisk regering under ledning av Per Albin Hansson. Som tidskriftens redaktör utsågs Daniel Brick, en mångsysslare av stora mått inom den sionistiska rörelsen. Han arbetade för Judisk krönika från dess bildande till 1979, nästan femtio år! Bricks hustru Anna Riwkin var tidskriftens fotograf, också hon en långvarig medarbetare.

Judisk krönika var inte den enda judiska tidskrift som utgavs i Sverige. Många, såsom Via Suecia, Unser Blatt, Vår Röst, Aktuellt, Kontaktbrev och Exodus, gavs ut under en kortare tid som upplysningsblad för judiska flyktingar. De kom ut på flera språk, en del med statsunderstöd. Andra kom ut regelbundet under en längre tid, såsom Judisk Tidskrift och Församlingsblad för Stockholms Mosaiska församling.

Det är Judisk krönika som står i blickpunkten för Karin Sjögrens avhandling Judar i det svenska folkhemmet. Minne och identitet. i Judisk krönika 1948-1958. (Brutus Östlings Bokförlag Symposion, 
Stockholm/Stehag 200I, 239 s.) Hon genomför en analys av hur det sionistiska engagemanget i Judisk krönika kom till uttryck i judiskt vardagsliv i Sverige under perioden 1948 -I958 mitt i det socialdemokratiska folkhemsbygget. Mycket tyder på att 1948 var en vattendelare i tidskriftens historia. Tidskriftens tidigare kulturorienterade inriktning innebar att en välutbildad grupp av företagare, politiker och byråkrater skrev till en läsekrets tillhörande en bildad medelklass. Efter andra världskrigets slut och tillkomsten av staten Israel 1948, fick det litterära materialet dela plats med nyheter, politik, ekonomi och inte minst vardagligt material. Förnyelsen var nödvändig med tanke på den bredare läsekretsen, framför allt de judar som kommit som flyktingar och överlevande från Förintelsen. Under 1930-talet fanns ca. 7000 judar i Sverige, strax efter andra världskriget var de ca. I3000. Judisk krönika skiftade innehåll på grund av en mera heterogen läsekrets och den starka kopplingen till staten Israel och sionismen.

Två begrepp är centrala i avhandlingen: minne och historia. Sjögrens grundläggande frågeställning är hur minne och historia förankrades hos judarna i femtiotalets Sverige. Den nybildade staten Israel började skriva landets officiella historia och formulera förståelsen av det förgångna. Det fick betydelse för hur minne och historia uppfattades $\mathrm{i}$ den svensk-judiska diasporan. Eftersom Judisk krönika på I950-talet blev den sionistiska rörelsens främsta språkrör i Sverige och Skandinavien, utgår författaren från att urvalsprocessen av innehăllet var ideologiskt styrd. Sjögren frågar sig om det fanns händelser, personer, episoder och högtider som inte fick plats och som skulle ha kunnat presentera ett annat perspektiv.

Genomgående betraktar författaren text och bild i Judisk krönika som sociala och kulturella konstruktioner med sina egna former för att representera verkligheten bakom iscensättningen av staten Israels nationsbygge. Sjögren utgår från Benedict Anderson och hans kända begrepp "föreställd gemenskap", som kännetecknas av att medlemmarna i varje nation ändå aldrig kommer att lära känna mer än en bråkdel av de övriga medlemmarna i sin upplevda gemenskap. Ändå lever bilden av denna gemenskap $i$ vars och ens medvetande. Den grundar sig på föreställningen om ett sammanhållande öde både i det förflutna och i framtiden. I mångt och mycket handlar det om den 
nationella identitetens känslomässiga ursprung. Utöver Anderson har Sjögren valt Ernest Gellner som teoretisk inspiratör. Gellner ser nationalismen som en funktion av en begynnande industrialisering och modernisering med politiska förtecken. Den tredje inspirationskällan har varit engelsmannen Eric Hobsbawm, som ser nationalismen som en ideologisk konstruktion i försöken att underminera l'ancien regime och bygga upp samhällen med upplysning och framåtsträvande som ideal. Enligt Sjögren bygger ett folks nationella samhörighet inte på blodsgemenskap eller den rådande befolkningssammansättningen, utan på känslan för och kunskap om historisk kontinuitet som finns i människors medvetande. Föreställningar om tillhörighet till det judiska folket medför inte heller nödvändigtvis att man lever på en bestämd plats eller talar ett särskilt språk.

Trots att det inte finns kvantitativt säkra källor om prenumeranter, utgår författaren från att Judisk krönika med sin riksspridning intog en central plats som sionistiskt språkrör för både en judisk och en icke-judisk läsekrets. Oturligt nog har alla prenumerantlängder försvunnit i en brand på redaktionens vindskontor. Vi vet alltså inte säkert hur stort inflytande Judisk krönika egentligen hade. Eftersom tidskriften är avhandlingens huvudkälla är frågan viktig för de slutsatser som dras om judiskt minne, historia och identitet och det sionistiska engagemanget. Kanske var en minoritet av judarna i Sverige prenumeranter? Var tidskriften möjligen bara östjudarnas och flyktingarnas tidning? Jag instämmer givetvis i påståendet att tidningar och tidskrifter vid denna tid spelade en avgörande roll som opinionsbildare eftersom Radiotjänst då bara hade en enda kanal och TV knappt hade börjat sända. Men här finns ett källmässigt problem som borde ha fătt ett kort metodologiskt avsnitt i början av avhandlingen. Även om det är ganska troligt att tidskriften faktiskt var vitt spridd i både judiska och icke-judiska kretsar, vet författaren egentligen inte hur "vitt spridd" (s ro, I8 i avh.) den var.

Huvudkällan har alltså varit samtliga nummer av tidskriften under perioden 1948-1958. Författaren har också nyttjat annat samtida otryckt material från judiska församlingar i Sverige på Riksarkivet och på Stadsarkiven i Malmö och Göteborg. Judiska nationalfondens arkiv i Jerusalem och Nordiska museets arkivsamling "Judiska minnen" har också kommit till användning. Författaren trycker särskilt 
på svårtillgängligheten på Riksarkivets stora deponering, som inte var komplett katalogiserad vid tiden för avhandlingsarbetet. Hon reserverar sig för problemen med representativitet och ofrivilligt slumpmässiga i urvalet. Jag kan bara instämma i detta med egna erfarenheter. Men hoppet är inte ute för framtida forskare, eftersom stockholmsförsamlingen nu erhållit två större anslag för genomgång och katalogisering av det digra materialet. Ett arbete som, vad jag förstår, redan påbörjats. Slutligen har Sjögren genomfört ett tjugotal djupintervjuer med flyktingar och överlevande.

\section{KOLleKTIVT MINNE OCH HISTORIA}

Varje benämning av de judar som kom från arbets- och förintelselägren uttrycker enligt författaren ett maktperspektiv. De kunde beskrivas som frigivna, flyktingar, repatriander, nykomlingar eller överlevande. Begrepp som det judiska folket syftar till att beteckna judarna som en enhet, men lika lite som judarna i Sverige utgjort en enhetlig grupp vad beträffar bakgrund, yrke, språk eller religiös övertygelse, kan vi tala om en homogen världsjudenhet. Författaren har inte strävat efter en entydig definition, då människorna i hennes källmaterial så tydligt själva definierar sig som judar. Medan nation och nationalitet var relativt sena begrepp i Västeuropa utgjorde judarna långt tillbaka i tiden en klart definierad social kategori som betraktades som en nation.

Sjögren ser både ett samband och en motsättning mellan kollektivt minne och historia. Hon hänvisar bl a till fransmannen Maurice Halbwachs, som ser dessa som två motstridiga berättelser om det förflutna, där historia är en vetenskaplig rekonstruktion och minne mera som en del av det sociala livet i konstant förändring. För den israeliske antropologen Yael Zerubavel rör sig det kollektiva minnet ständigt fram och tillbaka mellan historiska källor och rådande sociala och politiska program.

Teologiska tolkningar har historiserat mytologiska berättelser och mytologiserat falska historiska skeenden. Minnet är enligt författaren själva livsnerven inom judendomen, där de bibliska berättelserna är centrala och upprepas ständigt generation efter generation genom 
ritualer kopplade till högtider och hågkomster. Det ger tillfälle till förverkligande av den föreställda gemenskapen. Huruvida de traditionella berättelserna överensstämmer med empirisk historieskrivning är av underordnad betydelse: det är betraktarens övertygelse som är rättesnöret. Här har Sjögren kopplat minnet till kulturgeografernas belysning av det synliga landskapet som skapas till ett lager av föreställningar som stöd för den nationella gemenskapen både i det kollektiva minnet och i nuet. Det är inte bara personer och episoder som blir betydelsebärande, också platser kan bli det. Staten Israels nationella berättelser fungerar som sammansvetsande ursprungsmyter (såsom legenden om Massada). Symboler produceras, bevaras och överförs för att motivera politiska handlingar. Sjögren belyser detta med flera exempel. Ett är Dan Rabinowitz' studie av den "nya" israeliska staden Natzerat Illit. Ur israeliskt perspektiv grundades staden 1957 och framställdes som obebodd och ödelagd i generationer, återerövrad genom idogt arbete. Försvaret av judisk närvaro stödjer sig på moralisk rätt till platsen genom arbete. Därmed förnekas de palestinska medborgarna i Israel sina tolkningar avseende samma ort. Mytologiseringsprocesssen blir samtidigt en uteslutningsprocess.

Här saknar jag en problematisering av de kända begreppen konstruktion, konstruktivism, essentialism osv. Utifrån sina teoretiska inspiratörer Anderson, Gellner, Hobsbawm och andra betraktar författaren, som nämnts, både text och bild i Judisk krönika som sociala och kulturella konstruktioner av sionism och israelisk nationalism. Författaren placerar sig inte i det sammanhang där hon uppenbarligen befinner sig, nämligen, den breda diskursen om essentialism och konstruktivism, för att inte tala om striden mellan traditionella historiker och postmodernister. Därmed förhåller hon sig inte heller till de begrepp som hon flitigt utnyttjar.

Ytterligheterna i debatterna kring de postmodernistiska åsikterna om att vi helt enkelt inte kan fånga verkligheten i våra beskrivningar över huvudtaget, är ju kända. I den extrema postmodernistiska diskursen är all historieskrivning enbart våra egna berättelser som ingenting har med verkligheten att göra. Den andra extremen är ju essentialisternas åsikter om att t.ex. kvinnlighet eller judisk identitet uteslutande är av naturen givna konstanter som aldrig förändrats. Sjögren berör flyktigt denna problematik på ett enda ställe $\mathrm{i}$ avhand- 
lingen, där hon skriver att genom att betrakta minnet som socialt och kulturellt konstruerat blir "det förgångna inte oåterkalleligen fixerat". Men att "detta konstruktivistiska sätt att förhålla sig till historien också öppnat vägen för förnekelsen av historiska grymheter" (s I6). Så är det förvisso. En för långt driven konstruktivism leder lika fel som en för långt driven essentialism. Vilken är Sjögrens definition av begreppet konstruktion? Handlar den sionistiska och nationalistiska diskursen enbart och uteslutande om konstruktioner? Vad är konstruerat och vad grundar sig på verifierbara företeelser? Det måste i slutändan ändå bli en empirisk fråga. Det problematiska är väl att judiskt minne och historia har kännetecknats av både kontinuitet och förändring.

\section{SIONISMENS RÖTTER OCH RÖRELSENS SVENSKA FÖRANKRING}

I avhandlingens tredje kapitel går författaren igenom världssionismens rötter och den sionistiska rörelsen i Sverige. I Judisk krönika gavs Theodor Herzl under 1950-talet den avgörande rollen som grundare av den politiska sionismen. Under sin tid som journalist i Paris blev Herzl starkt påverkad av Dreyfus-affären och övertygad om att svaret på antisemitismen inte var assimilation utan en politisk lösning för alla judar. Antisemitismen var ofrånkomlig, judarna måste äntligen få ett eget territorium, Der Judenstaat. Stödet för dessa ideer kom inte från Europas välsituerade judar, den fanns i stället hos galiciska, polska och ryska gettoproletariatet som attraherats av tidens socialistiska ideer.

Ur den första sionistiska världskongressen i Basel I897 utkristalliserades flera motsättningar bl a den om hur man skulle betrakta Palestina/Israel. I motsats till dem som ville se landet som ett kulturellt centrum ville Herzl vidga bilden till ett nationellt, andligt och kulturellt hemland.

Theodor Herzl fick stor publicitet i Sverige. Den på sin tid mycket kontroversielle europeiske kulturpersonligheten framställdes i tidskriften som helt okontroversiell. Hans karisma visar hur stort behovet av en förgrundsgestalt verkligen var. Judisk krönika publice- 
rade utdrag ur Herzls romaner och tal, artiklar skrevs om hans insatser för judisk kultur. Han uppmärksammades i radioprogram, utställningar, dokumentärfilmer och seminarier. Kunde Theodor Herzl, en assimilerad juder född i. Ungern, uppfostrad i Wien och verksam i Paris, utan att drivas av någon religiös känsla, fördjupa sig i det judiska folkets problem, kunde judar i Sverige också göra det.

I Sverige togs de första initiativen till sionistisk verksamhet av de från Östeuropa invandrade judarna som bosatt sig i Lund och Malmö. Med tiden utvecklades starka motsättningar mellan de etablerade och de nyinvandrade judarna, vilket framkom inte minst på den första sionistiska konferensen i Stockholm 19I3. Rabbinen Gottlieb Klein tillhörde den liberala judendomen och vände sig häftigt mot den judiska nationalismen. Han tog till orda i Dagens Nyheter och skrev under rubriken "Hvarför äro svenska judarna icke zionister" bl.a. "ingenting (med hänsyftning till antisemitismen) tvingar oss till en onaturlig kulturell afskildhet, och uppväcker i oss de chauvinistiska instinkter som ofta utgör den starkaste bevekelsegrunden i denna propaganda", vidare, att det som löpte som en röd tråd genom Israels historia var bevarandet av religionen, inte nationaliteten. Rabbi Kleins åsikter var representativa för tidens reformjudendom också på den europeiska kontinenten.

Ingen svensk sionist gick i svaromål mot stockholmsförsamlingens officiella ståndpunkt. Klein fick svar i Aftonbladet av en tysk sionist, Gerson Bloede, under rubriken "Varför judarna är zionister". Diskussionerna gav eko också i den icke-judiska pressen. Klein fick ett indirekt svar också i Svenska Morgonbladet 9/8 I9I3, där tidningen tog fasta på den sionistiska rörelsens nationalfond: "I besittning af eminenta finansiella egenskaper som judarna i allmänhet äro, förstår zionismen att hvad den framför allt behöfver är pengar. /.../ Det vill dock förefalla som om zionismen icke skulle ha de rikaste judarna med sig. /.../ Men de tillhöra förmodligen icke till rasens drömmare, som vilja genom praktiska åtgärder förverkliga ett ideellt mål”. Så kunde också vardagsantisemitismen i Sverige komma till uttryck. Kleins efterträdare, Stockholms nye rabbin Marcus Ehrenpreis, var visserligen inte heller drivande i sionistiska frågor, men han motarbetade inte deras verksamhet. Ehrenpreis' arriklar i Judisk krönika om livet $i$ Israel och den judiska ungdomen där hade stor bety- 
delse för det sionistiska engagemanget.

Men det är likväl tydligt att olika uppfattningar om sionismen uttryckte en djupare motsättning mellan två grupper inom svensk judenhet. Den ena gruppen tillhörde den välutbildade medelklassen som var sedan generationer välintegrerad i det svenska samhället. Den avvisade sionismen som osvensk. Den andra gruppen tillhörde första generationens östjudiska invandrare från sekelskiftet 1900. De tillhörde en kulturtradition som oftast hade starka band till socialism och sionism. Ett mönster som alltså gick igen också i övriga Europa. Senare ändrade många motståndare ståndpunkt. Det gjorde t.ex. Hugo Valentin, som blev en av den svenska sionismens förgrundsgestalter. Han var helt assimilerad och endast till namnet mosaisk trosbekännare. Enligt egen utsago blev han sionist vid fyrtiotre års ålder, efter att tidigare ha tagit avstånd från rörelsen. Likväl deklarerade han som sionist att "överge en förföljd gemenskap föll mig icke in". Genom hans anseende som historiker och debattör vanns enligt Sjögren många anhängare åt den sionistiska idén.

Den nationella sionismen innehöll socialistiska ideer som uppskattades av den svenska socialdemokratin. Kort efter Balfourdeklarationen I9I7 uttalade socialdemokraten Hjalmar Branting offentligt sitt stöd för det "pånyttfödda judiska folket" och hälsade den nya medlemmen i nationernas familj i Nationernas förbund. I920-talet blev en tid av växlande framgångar och bakslag för den svenska sionismen, men med 1930-talets ökande antisemitism ökade också antalet judiska liksom sionistiska föreningar. Under krigsåren förstärktes det judiska medvetandet ytterligare i och med att tyska, norska och danska judiska flyktingar började anlända till Sverige:

Andra världskrigets extrema förhållanden bidrog till en vitalisering av judiska och sionistiska aktiviteter i Sverige. Man höll en sionistisk konferens i Stockholm 1943 och något senare sammanträdde Skandinaviska Sionistförbundet, med Ehrenpreis som en av talarna. Han såg sionismen som en personlig angelägenhet eftersom den var sammanvuxen med "vår judiskhet och blev en levande kraft inom oss". Nu bildades också en (provisorisk) svensk sektion av World Jewish Congress.

Både under och efter andra världskriget var det omhändertagandet av de från koncentrations- och arbetsläger befriade judarna som 
sysselsatte de flesta judiska institutioner och tog de största resurserna i anspråk. Sjögren har intervjuat ett antal av dessa repatriandi och skildrar med stor empati deras utsatthet och svårigheter att inlemmas i det svenska samhället. För att omfattas av folkhemmets solidaritet gällde det för flyktingarna att arbeta för sitt uppehälle. De manliga flyktingarna anställdes främst inom skogs- och jordbruk och de kvinnliga inom sjukhus, restauranger, hotell samt inom textilindustrin. Barn och ungdomar placerades i skolhem och internat. Det var tydligt att inte heller flyktingarna närde någon förväntan på att samhället eller någon annan utomstående skulle rycka in med ekonomisk hjälp. Mosaiska församlingarna kunde också i brist på medel ibland neka till ekonomisk hjälp. Det är samtidigt slående hur stor vikt de intervjuade lade på utbildning. Det var något man medvetet eftersträvade, om inte för sig själv så för nästa generation.

\section{EXPONENTER}

Rubriken för avhandlingens kapitel fyra syftar på hur Judisk krönika integrerade olika företeelser till den sionistiska kontexten. Efter 1948 stod den ideologiska profileringen och nationen Israels uppbyggnadsarbete i centrum. Artiklar skrevs av många välkända skribenter, både judar och icke-judar. De kunde handla om Israels vetenskapliga utveckling, vad ledande män uttryckt (inte minst utgavs valda delar av David Ben-Gurions anföranden), information om Israels betydelse för världsjudenheten, rapporter från internationella organisationer, annonser, litteraturecensioner och kulturartiklar. Tidskriften utgav också en ungdomsbilaga.

Den primära uppgiften var att forma en svensk judisk identitet och förstärka identifikationen med "hemlandet", uppmuntra utvandring till Israel och skapa opinion för Israel och sionism i Sverige. Den 5 juli I950 antog Israels parlament "Lagen om återvändande" där det fastslogs att landet skulle vara ett nationellt "hem" för alla judar. Lagen gav varje jude ovillkorlig rätt att invandra till Israel och omedelbart erhålla medborgarskap. Sjögrens studier av medlemslängder inom stockholmsförsamlingen visar att det var vid mitten av I950talet som den mera omfattande utvandringen till Israel började. 
För majoriteten av Sveriges judar stod dock inte valet mellan att utvandra till Israel eller glömma sin judiska identitet. Judisk krönika väckte viktiga frågor och stämde till debatt: kunde assimilerade judar över huvudtaget ha judiska nationalkänslor? Och vem var egentligen sionist? För en del räckte det att man gav penningbidrag till Israel. Andra såg att en sionist var den som var beredd att emigrera till Israel. En tredje åsiktsriktning kunde hävda att en sionist kände skulle känna till de internationella debattfrågorna och teorierna. Judisk krönikas definition sammanföll med Hugo Valentins: en sionist var den som betraktade staten Israel som en del av sitt liv och kände sig förbunden med landet.

\section{JUDISKA NATIONALFONDEN}

Från I949 utkom en månatlig bilaga till Judisk krönika för Judiska nationalfonden (Keren Kajemet Leisrael) och Israels uppbyggnadsfond (Keren Hajesod). Idén om att köpa land i Palestina väcktes redan på i88o-talet av ryska judar, men nu började även förmögna personer som baron Edmond de Rothschild investera i Palestina. Den Judiska nationalfondens historia börjar med att den femte sionistiska världskongressen I9OI antar förslaget om upprättandet av en sådan fond. Efter att nationalfonden köpt upp områden i Palestina gällde det, enligt Sjögren, efter I948 att snabbt bosätta "övergivna" områden för att bygga upp staten Israel. Så blev fonden en garant för judisk kontroll av land. Sjögren blottar den motsägelsefylldhet i historieskrivningen om hur fonden tillsammans med staten blev den enda institution med fullmakt att genom överlåtelse förvärva "fientlig" samt av ägaren "övergiven" egendom. Lagen I950 uteslöt icke-judar från kontroll av den mark fonden förvärvat. Den israeliska konstruktionen av en nationell berättelse var att de araber som flydde 1948 gjorde det antingen av fri vilja eller för att de lyssnade till locktoner från de omgivande arabstaterna som försökte krossa den judiska staten. Den andra sidan, som inte framkom i Judisk krönika, var att många palestinier som lämnade sina hem utsattes för påtryckningar som ibland urartade till ren fördrivning. 


\section{DEN BLÅ BÖSSAN}

Judiska nationalfondens bössa introducerades i Sverige I910, men både fonden och bössan förblev ganska okända i över tjugo år. Ett tydligt tecken på detta var berättelsen i Judisk krönika 1949 om att bösstömmarna under de första åren avspisades med förklaringen att $\mathrm{i}$ det här huset finns inga skjutvapen! På r930-talet började bössorna finna sin väg till de mera välsituerade svenska judarna, men de var fortfarande frågan om blygsamma summor. Det var först vid staten Israels tillkomst som bössintäkterna började öka markant. Bössans popularitet kan också sökas i de judiska flyktingarnas erfarenheter av sionistisk insamlingsverksamhet redan i sina hemländer. I Judisk krönika kunde det stå 1949: "Dina slantar i den blå bössan betyder nytt liv för Israel" eller "Här finns möjlighet för alla skikt av folket, I .../ att göra demokratins mackabéertjänst för sig själv och Israel".

Bössan kunde kopplas till patriotisk identifikation med antikens frihetskämpar, den skulle uppväcka hågkomst av det förgångna och därmed trycka på den nutida moraliska plikten gentemot Israel. Den skapade kontakter, samtal och gemenskap, inte minst genom de otaliga bösstömningskampanjerna. I Judisk krönika I957 framhålls att det inte väsentligen var frågan om pengar utan i grunden om uppfostring till en inställning till judendom och Israel. Teckningen av landets kustlinje på bössans framsida skulle påminna om landets betydelse.

\section{MinnessKogaRnA}

Judisk religion har alltid varit förknippat med Israel. Påminnelserna om landet har återkommit i rabbinsk litteratur, i bönboken och i liturgin på högtider. Efter statsbildningen $1948 \mathrm{blev}$ många platser som förknippats med bibliska texter åter betonade, ibland fylldes de med nya betydelser. De bibliska beskrivningarna av det cederskogsklädda landet "som flöt av mjölk och honung" gav de europeiska pionjärerna en bild av landet med skogar liknande dem som fanns i Öst- och Västeuropa. De låga buskar de fann i Jerusalems omnejd och i Galiléen blev en besvikelse. Att återskapa de bibliska skogarna blev tidigt det stora projektet. Bild och text i Judisk krönika fram- 
ställde den nye israelen i idogt arbete med att omskapa ett kargt landskap till en blomstrande nation.

Sionistisk retorik såg en självklar kvalitativ skillnad i territoriet Israel och det som var utanför dess gränser. "Hemlandet" var säkert och stabilt medan diasporan var osäker och instabil. Landets berg, dalar, floder, träd och blommor gavs stark symbolisk kraft och levandegjordes med hjälp av bibelkunskap, undervisning i Talmud, den judiska religiösa lagtolkningstraditionen och historieundervisningen. Minnesskogarna var en form av topografisk och symbolisk knutpunkt för individuell och kollektiv åminnelse vars ursprung gick tillbaka till kristen europeisk tradition liknande de "hjältelundar" och "minnesparker" som fanns i Tyskland och Frankrike efter första världskriget.

\section{SIONISTISK TOLKNING AV HÖGTIDER}

Också högtider betraktades genom ett sionistiskt spektrum. Författaren tar upp tre högtider för att belysa detta (nyåret, trädens nyår och Israels nationaldag). I Judisk krönika under I950-talet förmedlades den judiska traditionen genom dessa högtider. Individens självrannsakan kopplades till Israels uppbyggnadsarbete, trädet fick symbolisera det judiska folket. Föreställningar om gemenskap territorialiserades i förhållande till bestämda landskap. Redan 1949 rapporterade tidskriften hur Israels oavhängighetsförklaring firades i Blå Hallen i Stockholms stadshus. Man betonade gemensamma mål mellan Sverige och Israel såsom fred, frihet och demokrati.

\section{KVINNORNA INLEMMADES I DEN SIONISTISKA GEMENSKAPEN}

Kvinnorna utgjorde, enligt Sjögren, 85-90\% av de judiska flyktingar som kom till Sverige våren $1945 . \mathrm{Nu}$ startades en bred rekryteringskampanj för att knyta dessa och andra kvinnor till den sionistiska kvinnoorganisationen WIZO (Womens International Zionist Organisation). Men här, liksom inom andra områden, uppkom motsättningen mellan de aktiva medelklasskvinnorna och de fattiga, ofta till 
både kropp och själ bräckliga flyktingskvinnorna. All kraft för dessa kvinnor gick till att börja sina nya liv, ofta inom låglöneyrken, och finna sig till rätta i det främmande svenska samhället. Under dessa förhållanden var det inte alltid lätt att finna motivation att ansluta sig till Wizo. Sjögren har intervjuat flyktingkvinnor som på ett gripande sätt vittnar om främlingskap och kommunikationssvårigheter på grund av olika bakgrund och erfarenheter mellan dem och de svensk-judiska kvinnorna.

Så småningom kunde dock de nya medlemmarna inlemmas i verksamheten, mycket på grund av att välgörenheten inte enbart riktades mot Palestina och Israel utan också inåt mot de nyvärvade kvinnorna, med kulturella kurser och regelrätt "immigrantkunskap". Sjögren ser paralleller mellan Wizo och folkbildningen inom svensk arbetarrörelse. Först efter 1948 kom svenska Wizo att arbeta uteslutande för Israel och religionen blev en vikrig del av verksamheten. Organisationen åtog sig $\mathrm{i}$ många sammanhang att representera Israel utåt. Man tog kontakt med icke-judiska kvinnoorganisationer, inbjöd judar som icke-judar till högtidighăllande av Israels nationaldag, tongivande representanter för andra kvinnoorganisationer inbjöds som talare.

Sjögren skriver att den sionistiska kvinnodebatten var dock inte helt befriad från koloniala stereotyper i ett samhälle byggd på europeisk fostran och europeiska värderingar. Så skulle icke-sionistiska orientaliska kvinnor som invandrat till Israel uppfostras för att "uppnå samma utvecklingsfas" som övriga israeliska kvinnor. Uppvuxna i arabisk miljö, lockade till Israel snarare av religion än sionism, fann de orientaliska judarna att landets tänkesätt inte helt respekterade deras kultur.

Folkhemmet liksom sionismen grundades på föreställningen om kollektivet, en enad nation skulle ta det moderna i besittning. Israel var också populärt i Sverige och stödet till Wizo och sionismen blev också ett svenskt projekt. Wizos representanter hävdade att de inte arbetade politiskt, det var frågan om information och välgörenhet. Men besöken i Israel blev till regelrätta pilgrimsresor varefter resenärerna blev ambassadörer i media för det "nya judiska livet" i Israel. Sjögren trycker särskilt på filmen som ett medium med stor genomslagskraft. Gemensamt för de filmer hon redogör för är dessutom 
frånvaron av intresset att teckna ett sympatiskt eller ens intresserat porträtt av en karaktär med arabisk bakgrund. De är i regel anonyma individer som tillhör ett våldsamt kollektiv medan de israeliska huvudkaraktärerna tillhör genomgående den västerländska kulturkretsen.

Det mesta i detta kapitel (och även på andra ställen i avhandlingen) handlar om hur israelisk nationalism kom till uttryck både i Israel och i Sverige. Även här saknar jag en diskussion och ett förhållningssätt till betydelsefulla begrepp såsom nationell identitet $i$ allmänhet och judisk nationalism i synnerhet. Enligt Sjögren bygger ett folks nationella gemenskap på känslan för och kunskap om historisk kontinuitet som finns i människans medvetande. "Samtidigt", skriver hon, "återstår att förklara varför nationen och de med nationen förknippade värdena har sådan beständig kraft i vår tid och manifesterar sådana stora skillnader $i$ innehåll och uttryck" (s 33). Frågan är befogad och Sjögren kunde gott ha fört något resonemang om nationalismen, som i globaliseringens spår både tappat kraft och samtidigt återväckts i mindre staters aggressiva nationalism.

Här hade några internationellt kända forskare kunnat vara till nytta. T.ex. den tyskfödde norske antropologen Fredrik Barth och hans tes om det ständiga vidmakthållandet av gränser mellan etniska grupper (också majoriteten i ett land är en etnisk grupp). Barth skriver i sitt mest kända verk Ethnic Groups and Boundaries att det är "the ethnic boundary that defines the group, not the cultural stuff that encloses it" (se Barth I969 s I5, 17, 32-33, 38). Han betonar alltså gränsernas betydelse på bekostnad av det etniskt-kulturella innehållet. Även om skillnaderna är konstruerade och knappt historiskt verifierbara, håller man fast vid särskiljande dikotomier mellan den egna gruppen och andra.

Den spanske sociologen Manuel Castells bok The Power of Identity löser det problem som enligt Sjögren återstår att förklara på ett annat sätt. Enligt honom är nationalism och internationalism/globalisering två parallella processer som pågår samtidigt. Starka uttryck för kollektiv identitet är enligt Castells en lättförståelig reaktion mot internationaliseringens anonymisering av individen (Castells I997 s 2-10).

Enligt den engelske sociologen Anthony Giddens i Modernity and Self-Identity upplöses det traditionella samhällets normer och institu- 
tioner genom krafter som han kallar "disembedding mechanisms", som i sin tur är en del av modernismen. Enligt Giddens struktureras livet allt mer av nya gränsöverskridande erfarenheter snarare än ritualiserade övergångar (Giddens I99I S I7-20). Enligt Castells pågår båda dessa processer parallellt.

\section{JUDISKT FEMTIOTAL}

Judisk krönika blev efter kriget ett kraftfullt språkrör för sionismen i Sverige. Artiklarna synliggjorde tydligt ett nationellt "vi" som fungerade exkluderande i förhållande till andra grupper. Sjögren visar vid läsningen av föreståndar- och fullmäktigeprotokoll från bl a malmöförsamlingen, där en stor den av de judiska flyktingarna bosatte sig, att det inte bara fanns ett nationell "vi" utan också ett "vi" och "de" inom församlingarna. Flyktingarna diskuterades aldrig i termer av tillgång utan som krav och hot.

Det fanns tydliga tecken på att Sverige under 1950-talet på allvar började framträda som ett sekulärt samhälle. Samtidigt med den stundtals direkt judefientliga debatten om skäktningen, pågick också en allvarlig diskussion om svenska kyrkans ställning och den lutherska läran. Judisk krönika ägnade inte angreppen på ritualslakten någon uppmärksamhet, men desto mer åt värvning av ungdomar till Israel och judiskt lägerarbete i Sverige under sionistisk fostran. $\mathrm{Nu}$ fick också debatten om en egen judisk skola stor uppmärksamhet.

Den föreslagna nya religionsfrihetslagen i början på 1950-talet förstärkte uppmärksamheten på de flesta församlingars konfessionella heterogenitet. Detta ökade oron för bildandet av nya små mosaiska församlingar. Enligt förslaget skulle anslutningen till religiösa samfund stå på frivillig grund, vilket skulle uppluckra beskattningsrätten på ett avgörande sätt. Det fanns en stark rädsla för massutträde med åtföljande inskränkningar i de svenska judarnas församlingsverksamhet. Ombedd att analysera de mosaiska församlingarnas ståndpunkter tog professor Eli F. Heckscher upp motsägelserna i deras argumentation och ansåg att man under skenbar anslutning till religionsfrihetsprincipen i praktiken gav upp den för att tillgodose församlingarnas intresse av att ha så många avgiftsbetalande medlemmar 
som möjligt. Den statliga kommitten gick på Heckschers linje och avslog alla förslag på särbehandling. Under påverkan av debatten, började församalingarna att vidta åtgärder för att bibehålla sina medlemmar. Malmö- och stockholmsförsamlingarna sänkte skatterna i flera procentenheter och tog bort kopplingen av medlemskap till svenskt medborgarskap.

Det svenska folkhemmets syn på Israel under 1950-talet var positiv. Israel inkluderades i svensk politik och kulturliv. Både i Judisk krönika och den svenska pressen var bilden av Israel i hög grad en projicering av egna visioner. Sjögren anar vid läsningen av samtida socialdemokratisk och liberal press att svenska delegationer uppfattade det israeliska intresset för Sverige som en bekräftelse på den "svenska modellen". Inte minst skildrades Israels kibbutzrörelse i massmedia ibland med idealiserande drag. Sa man ja till det svenska samhället, sa man också ja till det israeliska, skriver Sjögren. Uppbyggandet av staten Israel hade ännu inte blivit en i grunden kontroversiell fråga.

\section{Avslutning}

Sammanfattningsvis kan Karin Sjögrens avhandling sägas ge en hel del ny kunskap om hur judiskt minne och historia påverkats och formats av Judisk krönika, tidens främsta sionistiska språkrör i Sverige. Tidskriften nådde också långt utöver den judiska kretsen och förmedlade en positiv kontakt mellan folkhemmet Sverige och den unga staten Israel. Samtidigt måste det konstateras att författaren inte helt lyckas integrera sina teoretiska inspirationskällor i det löpande resonemanget. Viktiga teoritunga begrepp sätts inte i arbete för att främja avhandlingens huvudsyfte. Genomgången ovan tydliggör också att delar av avhandlingen ger intryck av en deskriptiv "katalogaria". Det är som om författaren tappar den röda tråden och förvillar sig i alla "intressanta" detaljer. T.ex. i kapitel IV behandlas under rubriken "Minnesskogar" inte bara skogsplanteringar och deras symboliska betydelse utan också ceremoniell begravning av kända judar från Europa, judisk invandring och lagen om återvändande samt hur kvinnor och män porträtterades i bildmaterialet i Judisk 
krönika. Under rubriken "Trädens nyårsdag" tar redogörelsen för mordet på FN-medlaren Folke Bernadotte överhanden och det största utrymmet. Också i kapitel V försvinner den röda tråden om Judisk krönika som organisatör av sammanhanget och aktuella dagsfrågor får stå i fôrgrunden. Alla möjliga frågor framtonar osorterade, såsom den om den judiska skolan, den efterkrigstida ersättningen från Tyskland till nazismens offer, grundandet av Chinuch osv. Visserligen finns flera hänvisningar till Judisk krönika, men utan rangordning dvs utan att författaren själv förhåller till alla dessa frågor.

I övrigt framstår själva bildmaterialet i tidskriften som högintressant och kunde ha kommenterats i högre grad. Jag tänker främst på en genusanalys av hur och varför man konstruerat den judiska kvinnan och mannen som de framkommer i bilderna i Judisk krönika.

Språket i avhandlingen är levande och flyter bra. Avhandlingen är välskriven. Jag har hittat några få felstavningar och ibland är bildtexterna oläsligt små (se t ex $s$ II2). Möjligen kan man anmärka på not 8 (i texten s I3, bland noterna s I9I). I texten sägs de verk som nämns $\mathrm{i}$ noten visa på forskning om den roll judisk kultur spelat i utvecklingen av det svenska samhället. De verk som redovisas pekar inte på denna roll utan mera på den judiska kulturgärningen i sig. 


\section{RIKTLINJER \\ för manuskript till Nordisk Judaistik}

\section{Allmänna instruktioner}

Manuskript (artikel - recension - debattinlägg) skall vara författat på danska, norska, svenska, tyska, franska eller engelska. Artiklar bör ha ett omfång om ca. 4000-10000 ord, recensioner 500-I500 ord, och skickas till redaktionen på diskett (skrivet i Word eller WordPerfect, alternativt konverterat till dessa) jämte en utskrift. Ej antagna artiklar returneras ej.

Författare till antagna artiklar făr tillsänt 5 särtryck av sitt bidrag när tidskriften publicerats.

\section{Manuskriptets utforming}

a. Fotnoter bör hållas så korta som möjligt, numreras fortlöpande och anges $i$ texten med en upphöjd arabisk siffra.

b. Artiklar skall förses med en litteraturlista som nämner använda verk. För litteraturlistans utformning, var vänlig följ nedanstående exempel: Urbach, Efraim E., 1979. The Sages. Their Concepts and Beliefs. Jerusalem. Friedman, Menachem, 1989 . "The State of Israel as a Theological Dilemma" i: B. Kimmerling, The Israeli State and Society, Albany, 165-215.

Kieval, Hillel J., 1997. "Persuing the Golem of Prague: Jewish Culture and the Invention of a Tradition", i: Modern Judaism, vol 17, I-23.

c. Litteraturhänvisning bör ske genom efternamn och sidonummer (t.ex. Idel, I55). Flera verk av samma författare markeras med årtal (Idel 1988, I6o) och i tillbörliga fall genom en kompletterande bokstav om man refererar till flera verk av samma författare från samma utgivningsår (Idel I987a, I68; Idel i987b, 66)

d. Rubriker sätts i någon större grad (punktstorlek) än huvudtext. Nytt stycken markeras genom dubbel radbrytning. Använd kursivering för att framhäva text; undvik att använda fetstil, understrykningar och / eller spärrande av ord för detta syfte. Citat, längre än tre rader, skrivs som självständigt stycke, utan citattecken och med mindre grad (punktstorlek) än övrig text. Utelämnade ord / meningar i citat markeras med tre punkter (...).

e. Citat på andra språk än danska, norska, svenska, tyska, franska eller engelska skall följas av en översättning till något av dessa.

f. Hebreiska, grekiska och arabiska (och andra) alfabeten kan användas. Undvik om möjligt diakritiska tecken vid transkribering.

g. Artiklar på skall åtföljas av en abstract på engelska om ca 200 ord.

h. Insända manuskript skall innehålla upplysningar om författarens namn samt adress (institutionsadress eller privatadress).

\section{Guidelines in English}

for articles submitted for publication are available from the office of publication. 